\title{
Ozone and hydrogen peroxide during summer smog episodes over the Swiss Plateau: Measurements and model simulations
}

\section{Citation}

Dommen, Josef, Albrecht Neftel, Andreas Sigg, and Daniel J. Jacob. 1995. “Ozone and Hydrogen Peroxide During Summer Smog Episodes over the Swiss Plateau: Measurements and Model Simulations." Journal of Geophysical Research 100, issue D5: 8953-8966.

\section{Published Version}

doi:10.1029/94JD03124

\section{Permanent link}

http://nrs.harvard.edu/urn-3:HUL.InstRepos:14117771

\section{Terms of Use}

This article was downloaded from Harvard University's DASH repository, and is made available under the terms and conditions applicable to Other Posted Material, as set forth at http:// nrs.harvard.edu/urn-3:HUL.InstRepos:dash.current.terms-of-use\#LAA

\section{Share Your Story}

The Harvard community has made this article openly available.

Please share how this access benefits you. Submit a story.

\section{Accessibility}




\title{
Ozone and hydrogen peroxide during summer smog episodes over the Swiss Plateau: Measurements and model simulations
}

\author{
Josef Dommen \\ Institute for Atmospheric Physics, Swiss Federal Institute of Technology, Zürich
}

\author{
Albrecht Neftel and Andreas Sigg \\ Swiss Federal Research Station for Agricultural Chemistry and Environmental Hygiene, Liebefeld-Bern
}

Daniel J. Jacob

Earth and Planetary Sciences, Division of Applied Science, Harvard University, Cambridge, Massachusetts

\begin{abstract}
As part of the POLLUMET (Pollution and Meteorology in Switzerland) study, measurements of $\mathrm{O}_{3}, \mathrm{NO}_{2}$, and $\mathrm{H}_{2} \mathrm{O}_{2}$ were made at ground stations, by aircraft, and manned hydrogen balloons to characterize the photochemical processes prevailing during times of high ozone production. During summer smog episodes, elevated ozone concentrations were found over the whole area of the Swiss Plateau, which is a densely populated and industrialized region. However, $\mathrm{NO}_{2}$ concentrations were generally at a low level in the afternoon. An increase of hydrogen peroxide concentration in the mixing layer during photochemical episodes was observed. To understand better the photochemical processes which control ozone formation over the Swiss Plateau, calculations with the Harvard photochemical model and the Harwell photochemical trajectory model were conducted. A comparison of model results with measurements of the triad $\mathrm{O}_{3}, \mathrm{NO}_{2}$, and $\mathrm{H}_{2} \mathrm{O}_{2}$ indicates an ozone formation under low $\mathrm{NO}_{x}$ conditions.
\end{abstract}

\section{Introduction}

The Swiss Plateau, located between the mountains of the Alps and the Jura, is a large, densely populated and industrialized valley (Figure 1). The topography restricts ventilation and stimulates the development of summer smog episodes. Surface ozone levels exceed regularly the air quality standard (62 ppb, allowed to be exceeded once an hour within a year). In 1989 a coordinated research effort was started to investigate ozone formation over the Swiss Plateau. The program POLLUMET (pollution and meteorology) was centered around several intensive observation periods (IOPs) in the summer months. The objective of the IOPs was to identify the processes regulating ozone concentrations.

Ozone is produced rapidly in polluted air by photochemical oxidation of volatile organic compounds (VOC) in the presence of nitrogen oxides $\left(\mathrm{NO}_{x}=\mathrm{NO}+\mathrm{NO}_{2}\right)$. The production may be limited by the availability of $\mathrm{NO}_{x}$ (low$\mathrm{NO}_{x}$ regime) or VOCs (high-NO $\mathrm{NO}_{x}$ regime). One of the key questions related to the occurrence of high-ozone episodes over the Swiss Plateau is whether ozone production is VOC or $\mathrm{NO}_{x}$ limited. Photochemical model calculations by Kleinman [1986, 1991] indicate that peroxides represent a sensitive indicator of low- versus high- $\mathrm{NO}_{x}$ regime. Therefore concurrent measurements of $\mathrm{O}_{3}, \mathrm{H}_{2} \mathrm{O}_{2}$, and $\mathrm{NO}_{2}$ concentrations should help to determine the regime for $\mathrm{O}_{3}$ production.

In this study we present measurements of $\mathrm{O}_{3}, \mathrm{H}_{2} \mathrm{O}_{2}, \mathrm{NO}_{2}$ Copyright 1995 by the American Geophysical Union.

Paper number 94JD03124. 0148-0227/95/94JD-03124\$05.00 concentrations, and meteorological parameters over the Swiss Plateau from the surface through the mixed layer to the troposphere above the boundary layer. Airborne measurements were made with a manned balloon and a motor glider. The observations are interpreted using photochemical models to determine the regime for $\mathrm{O}_{3}$ production.

\section{Chemistry}

The atmospheric oxidation of hydrocarbons (RH) produces ozone in the presence of $\mathrm{NO}_{x}$ :

$$
\begin{gathered}
\mathrm{RH}+\mathrm{OH}+\mathrm{O}_{2} \rightarrow \mathrm{RO}_{2}+\mathrm{H}_{2} \mathrm{O} \\
\mathrm{RO}_{2}+\mathrm{NO}+\mathrm{O}_{2} \rightarrow \mathrm{NO}_{2}+\mathrm{HO}_{2}+\mathrm{R}^{\prime} \mathrm{CHO} \\
\mathrm{HO}_{2}+\mathrm{NO} \rightarrow \mathrm{NO}_{2}+\mathrm{OH} \\
\left.\mathrm{NO}_{2}+h v \rightarrow \mathrm{NO}+\mathrm{O}^{3} \mathrm{P}\right) \\
\mathrm{O}\left({ }^{3} \mathrm{P}\right)+\mathrm{O}_{2}+\mathrm{M} \rightarrow \mathrm{O}_{3}+\mathrm{M}
\end{gathered}
$$

The mechanism requires the presence of $\mathrm{HO}_{x}$ radicals $\left(\mathrm{OH}+\mathrm{HO}_{2}\right)$. The major sources of these radicals are the photolysis reactions

$$
\begin{gathered}
\mathrm{O}_{3}+h v \rightarrow \mathrm{O}\left({ }^{1} D\right)+\mathrm{O}_{2} \\
\mathrm{O}\left({ }^{1} D\right)+\mathrm{H}_{2} \mathrm{O} \rightarrow 2 \mathrm{OH} \\
\mathrm{RCHO}+h v+2 \mathrm{O}_{2} \rightarrow \mathrm{HO}_{2}+\mathrm{RO}_{2}+\mathrm{CO}
\end{gathered}
$$

Loss of $\mathrm{NO}_{x}$ and $\mathrm{HO}_{x}$ is by (R8)-(R11):

$$
\mathrm{HO}_{2}+\mathrm{HO}_{2} \rightarrow \mathrm{H}_{2} \mathrm{O}_{2}+\mathrm{O}_{2}
$$




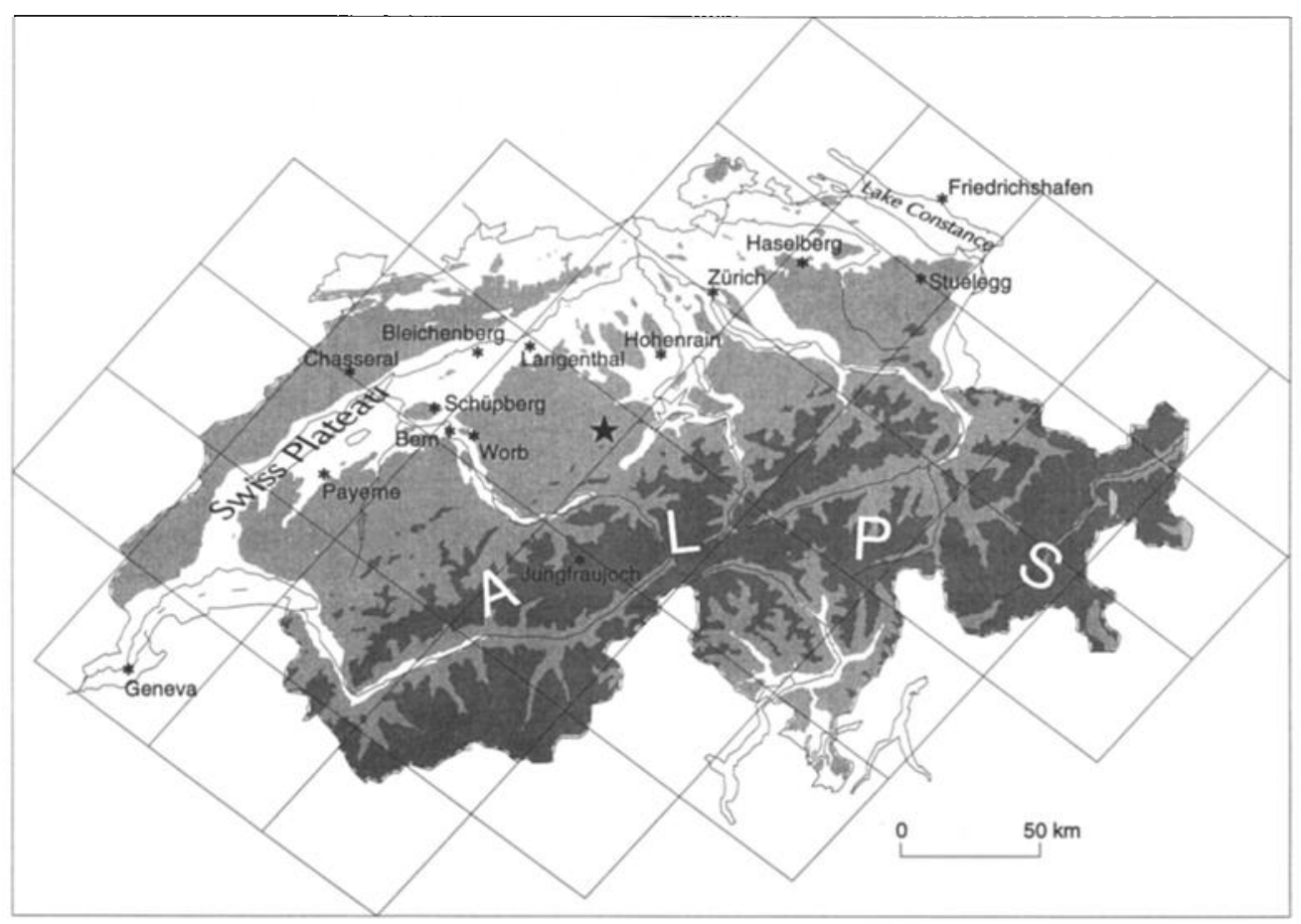

Figure 1. Map of the Swiss Plateau with the Organization for Economic Cooperation and Development grid. Principal urban centers and selected measuring stations are shown. The star indicates the Bernese grid cell.

$$
\begin{gathered}
\mathrm{HO}_{2}+\mathrm{RO}_{2} \rightarrow \mathrm{ROOH}+\mathrm{O}_{2} \\
\mathrm{NO}_{2}+\mathrm{OH}+\mathrm{M} \rightarrow \mathrm{HNO}_{3}+\mathrm{M} \\
\mathrm{RCOO}_{2}+\mathrm{NO}_{2}+\mathrm{M} \rightleftarrows \mathrm{RCOO}_{2} \mathrm{NO}_{2}+\mathrm{M}
\end{gathered}
$$

The $\mathrm{NO}_{x}$ and $\mathrm{HO}_{x}$ radicals are chain carriers in the ozone production (reactions (R1)-(R7)), while the hydrocarbons are consumed. If the $\mathrm{NO}_{x}$ concentration is low, the termination reactions (R8) and (R9) compete with the chain reactions (R2) and (R3), leading to the production of peroxides (low- $\mathrm{NO}_{x}$ regime). If the $\mathrm{NO}_{x}$ concentration is high, (R10) scavenges $\mathrm{OH}$ (high- $\mathrm{NO}_{x}$ regime), suppressing the formation of peroxides. Measurements of peroxide concentrations offer thus a diagnostic tool of the photochemical regime.

\section{POLLUMET Field Campaigns}

Two field studies were conducted in the summer of 1990 (June, July) and 1991 (July, August). There were two types of measurements: (1) routine measurements taken throughout the 2-month period and (2) additional measurements during the 2- to 5-day intensive observation periods (IOP90 from July 23 to July 30, 1990, and IOP91 from July 9 to 11, 1991). Routine data included the Automatic Network of Weather Stations (ANETZ and ENET) and the surface air chemical monitoring network operated by the Swiss federal and cantonal authorities. The IOPs included additional measurements at the Schüpberg ground station, which is situated on a hill in the central part of the Swiss Plateau (see Figure 1), and airborne measurements with a manned balloon in 1990 and with a motor glider in 1991. Table 1 lists the instrumentation aboard the balloon and the motor glider.
IOP90 was timed at the end of a 2-week-long anticyclonic situation and encompassed the Swiss Plateau from the Lake of Geneva in the west to the region of Zurich in the east; for a detailed description of the meteorological situation, see Wanner et al. [1993]. IOP91 covered the buildup of a weak anticyclone and was confined to the region of Bern, the central part of the Swiss Plateau; it was aimed to gather a detailed cross section from the Jura Mountains to the Alps.

\subsection{Instrumentation}

Ground-based measurements of peroxides were made with a dual-channel instrument similar to the one described by Lazrus et al. [1986]. Ambient air at a rate of $2 \mathrm{~L} / \mathrm{min}$ was drawn through a glass coil, $1.5-\mathrm{mm}$ diameter times $50 \mathrm{~cm}$ in length, where gas phase peroxides dissolved in bidistilled water. The peroxides form a fluorescent dimer of 4-ethylphenol in the presence of the enzyme peroxidase. The dimer is detected by its fluorescence at $400 \mathrm{~nm}$. To control baseline drifts, the flow injection analysis technique was used. Calibration was routinely performed with aqueous standard

Table 1. Instrumentation of Airborne Platforms

\begin{tabular}{lll}
\hline Component & Balloon Cruises (IOP90) & Light Aircraft (IOP91)* \\
\hline $\begin{array}{l}\text { Pressure } \\
\text { Temperature }\end{array}$ & $\begin{array}{l}\text { Rosemount, capacitive } \\
\text { Vaisala, capacitive }\end{array}$ & $\begin{array}{l}\text { Rosemount, capacitive } \\
\text { Meteolabor, } \\
\text { thermocouple } \\
\text { chilled mirror }\end{array}$ \\
Humidity & Vaisala Humicap & UV absorption \\
Ozone & UV absorption & Luminox LMA-3 \\
$\mathrm{NO}_{2}$ & Luminox LMA-3 & enzymatic fluorimetry \\
$\mathrm{H}_{2} \mathrm{O}_{2}$ & enzymatic fluorimetry & encing
\end{tabular}

*A detailed description of the light aircraft is given by Neininger and Fuchs [1994]. 
solutions of $\mathrm{H}_{2} \mathrm{O}_{2}$ assuming a collection efficiency of $100 \%$ [Heikes, 1992]. After the coil the liquid sample was split into two channels. The first channel measured $\mathrm{H}_{2} \mathrm{O}_{2}$ and partly organic peroxides (see below). The second one passed a small column (ID $1.5 \mathrm{~mm}$, length $15 \mathrm{~mm}$ ) filled with $\mathrm{MnO}_{2}$ coated $\mathrm{Al}_{2} \mathrm{O}_{3}$ (grain size $0.5 \mathrm{~mm}$ ) which specifically destroys $\mathrm{H}_{2} \mathrm{O}_{2}$ with an efficiency $>97 \%, \mathrm{CH}_{3} \mathrm{OOH}$ by only $5 \%$, and hydroxymethyl hydroperoxide (HMHP) by $30 \%$ at most. The instrument had a detection limit of 0.1 parts per billion by volume (ppbv) and a time resolution of $5 \mathrm{~min}$. Measurements at the beginning of the field campaign in summer 1990 revealed that the signal of the second channel hardly exceeded the detection limit. Because of operational problems we then removed the $\mathrm{MnO}_{2}$ catalyst and measured with two channels in parallel.

For the balloon cruises and especially for the motor glider we built a special low-weight to low-power diffusion denuder system (DS) with a gas phase flow injection analysis configuration [Dasgupta et al., 1988; Sigg et al., 1992a, b]. The instrument contains an automatic gas phase calibration system. This is a Henry equilibrator, consisting of a 50-cm-long microporous polypropylene tubing (Accurel) immersed in an aqueous $\mathrm{H}_{2} \mathrm{O}_{2}$ solution which is thermostated to $5^{\circ} \mathrm{C}$ by Peltier elements. The resulting $\mathrm{H}_{2} \mathrm{O}_{2}$ partial pressure is calculated using the data of Lind and Kok [1986]. Zero air and calibration gas enter the sample inlet tubing only $5 \mathrm{~cm}$ after the inlet point. This configuration accounts for possible $\mathrm{H}_{2} \mathrm{O}_{2}$ losses in the inlet tubing, Air aspired continuously by the intake pump is alternately ambient air, zero air, or calibration gas.

The balloon monitor was constructed as a dual-channel instrument with two Nafion tubes in the glass pipe of the diffusion scrubber. Similar to the coil system, one channel passed a small $\mathrm{MnO}_{2}$ column which removed quantitatively $\mathrm{H}_{2} \mathrm{O}_{2}(>98 \%)$ in the liquid stream. Because of operational problems the organic peroxide channel worked only during the third balloon cruise. Because of space and weight restrictions in the pods of the motor glider, only a singlechannel instrument could be constructed for that purpose.

The detection limit of the DS under laboratory conditions is $0.05 \mathrm{ppbv}$ and the precision for ambient air with $1 \mathrm{ppb}$ of $\mathrm{H}_{2} \mathrm{O}_{2}$ is better than $5 \%$. The system is linear in the range 0.1-10 ppbv. Under field conditions, performance cannot be maintained at this high level, mainly due to temperature drifts. The detection limit is at $0.1 \mathrm{ppbv}$ and the precision at 1 ppbv better than $10 \%$. The coil system and the DS have been compared under field conditions and gave agreement within 10\% [Sigg and Neftel, 1993]. An interference of $0.4 \%$ to ozone has been determined for the DS. The accuracy of the DS critically depends on the Henry constant used to calculate the concentration of the internal calibration source. The reported values in the literature differ by more than $30 \%$ [Staffelbach et al., 1993], and the accuracy of the $\mathrm{H}_{2} \mathrm{O}_{2}$ measurement is no better than the uncertainty in the determination of the Henry coefficient.

The $\mathrm{H}_{2} \mathrm{O}_{2}$ measurements are subject to interference due to organic peroxides as listed in Table 2 . The sensitivity to $\mathrm{HMHP}$ and $\mathrm{CH}_{3} \mathrm{OOH}$ depends critically on the concentration of peroxidase and 4-ethylphenol as well as the reaction time. The coil system had a reaction time of $40 \mathrm{~s}$, whereas the single-channel DS used in the light aircraft had a reaction time of only $15 \mathrm{~s}$. The peroxidase concentration used was rather low. Because of these operational modes the DS
Table 2. Interference of Methylhydroperoxide (MeOOH) and Hydroxymethyl Hydroperoxide (HMHP) to the $\mathrm{H}_{2} \mathrm{O}_{2}$ Signal

\begin{tabular}{lccc}
\hline & $\begin{array}{c}\text { Standard } \\
\text { Solution }\end{array}$ & Coil System & $\begin{array}{c}\text { Diffusion Scrubber } \\
\text { System }\end{array}$ \\
\hline $\mathrm{H}_{2} \mathrm{O}_{2}$ & 1 & 1 & 1 \\
$\mathrm{HMHP}$ & $0.4-0.6$ & 0.6 & $0.15-0.3$ \\
$\mathrm{MeOOH}$ & 0.25 & 0.15 & $0.02-0.05$ \\
\hline
\end{tabular}

Numbers given are $\mathrm{H}_{2} \mathrm{O}_{2}$ equivalent per unit of organic peroxide.

system showed a quite good discrimination against soluble organic peroxides. Although the coil system showed higher interferences to organic peroxides, initial measurements with the $\mathrm{MnO}_{2}$ scavenging technique (see above) showed that signals hardly exceeded the detection limit $\left(<1 \% \mathrm{H}_{2} \mathrm{O}_{2}\right.$ equivalent). All reported $\mathrm{H}_{2} \mathrm{O}_{2}$ data in this paper are therefore given without corrections for organic peroxides. Such a correction would have been difficult because the mixture of organic peroxides is not known.

The ozone monitors on the balloon and the motor glider were miniaturized UV photometers, which were calibrated before and after each study against a MonitorLabs 8910 . For the airborne $\mathrm{NO}_{2}$ measurements only the Luminox instrument (LMA-3, Scintrex/Unisearch) met the requirements of fast response ( $1 \mathrm{~s})$, high sensitivity $(<0.1 \mathrm{ppbv})$, low-power consumption and low weight [Drummond et al., 1989]. The luminol technique suffers from an ozone and a peroxyacetylnitrate (PAN) interference; the ozone interference is about $0.3 \%$ of $\mathrm{O}_{3}$ for zero $\mathrm{NO}_{2}$ but can vary with luminol solution. PAN interference has been reported to be around $25 \%$ of PAN [Kelly et al., 1990]. The baseline of the system is very sensitive to temperature changes, despite a built-in signal processing which is intended to compensate temperature changes. Although ozone interference was corrected, the $\mathrm{NO}_{2}$ concentrations measured with the small aircraft have still an uncertainty of $1.5 \mathrm{ppbv}$ in the baseline.

The motor glider Stemme S10 VC, owned by the Swiss company MetAir, was described by Neininger and Fuchs [1994]. Chemical and meteorological instruments have been installed in two pods attached below the wings.

At some ground stations, commercially available differential optical absorption systems (DOAS) from the Swedish company OPSIS, which measured $\mathrm{O}_{3}, \mathrm{NO}_{2}$, and $\mathrm{SO}_{2}$, were used. For the $\mathrm{NO}_{2}$ measurements we determined a precision of $\pm 0.2 \mathrm{ppb}$ at an integration time of $1 \mathrm{~min}$. The offset had an uncertainty of $\pm 0.5 \mathrm{ppb}$.

\section{Experimental Data}

\subsection{Ground-Based Measurements}

To put things into perspective, we present the data from the rural station Schüpberg, northwest of the city of Bern, which we consider as representative of the regional pollution over the Swiss Plateau. It is located in a gently hilly agricultural area 100 to $200 \mathrm{~m}$ above the lowest and also flattest part of the Swiss Plateau. Figures $2 a$ and $2 b$ show the $\mathrm{O}_{3}, \mathrm{NO}_{2}, \mathrm{H}_{2} \mathrm{O}_{2}$, and $\mathrm{H}_{2} \mathrm{O}$ concentrations registered at this station. Two main differences emerge comparing the data from 1990 and 1991: (1) The water vapor and $\mathrm{H}_{2} \mathrm{O}_{2}$ concentrations were considerably lower during IOP90 than during 

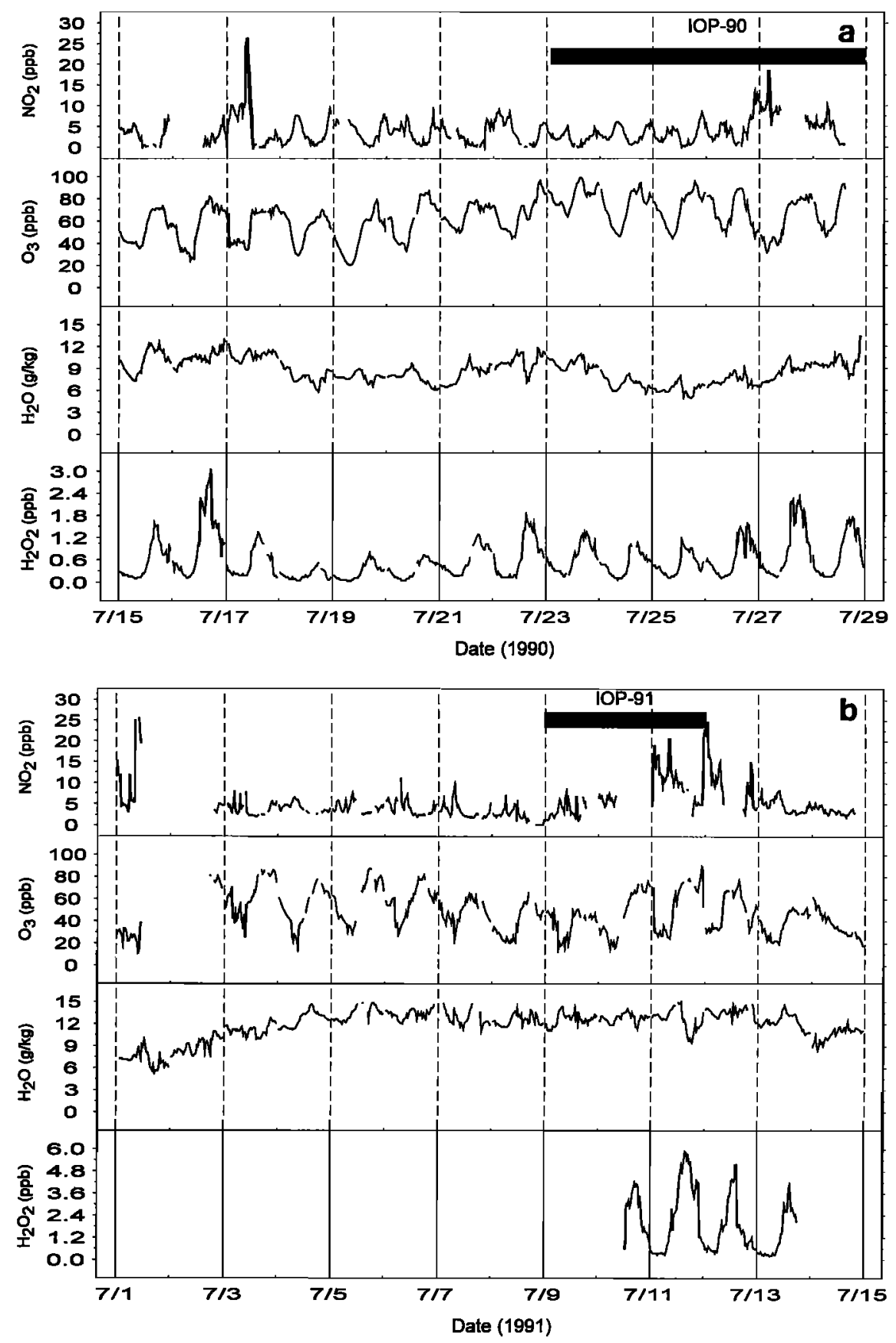

Figure 2. Concentrations of $\mathrm{O}_{3}, \mathrm{NO}_{2}, \mathrm{H}_{2} \mathrm{O}_{2}$, and $\mathrm{H}_{2} \mathrm{O}$ at the rural site Schüpberg. (a) 1990: $\mathrm{NO}_{2}$ was measured by DOAS (OPSIS analyzer), $\mathrm{O}_{3}$ with a DASIBI RS1008, and $\mathrm{H}_{2} \mathrm{O}$ with a conventional relative humidity instrument (Rotronic). $\mathrm{H}_{2} \mathrm{O}_{2}$ was measured with the system described in the text. Accuracy: $\mathrm{O}_{3}=3 \mathrm{ppb} ; \mathrm{NO}_{2}=0.5 \mathrm{ppb}$. (b) 1991: $\mathrm{NO}_{2}$ was measured with a Scintrex LMA-3. Because of problems with luminol solutions the offset might reach $2 \mathrm{ppb}$.

IOP91. $\mathrm{H}_{2} \mathrm{O}_{2}$ concentrations ranged between 0 to $3 \mathrm{ppb}$ in 1990 , while it reached $6 \mathrm{ppb}$ in 1991; (2) IOP90 took place at the end of a period with elevated ozone concentration, while IOP91 covered the buildup of a "summer smog" episode. During such periods of 3-5 days the buildup of ozone concentration usually levels off around 80-100 ppb [Künzle and $\mathrm{Neu}, 1994]$.

In $1990 \mathrm{H}_{2} \mathrm{O}_{2}$ concentrations increased during the two episodes July 18-23 and 24-26 at a rate of about $0.3 \mathrm{ppb} / \mathrm{d}$.
Because of operational problems we could not follow the full buildup during IOP91.

Mean average $\mathrm{NO}_{2}$ concentrations in the afternoon at the Schüpberg station fell below 1 ppb. Even more, DOAS instruments of cantonal authorities located in the city of Bern and the semirural area of Worb also recorded values of similar low concentrations. It should be pointed out that in the case of the Swiss Plateau the rural character of a location is relative in view of the dense population. Table 3 summa- 
rizes the average $\mathrm{NO}_{2}$ concentrations from July 21 to July 28,1990 , observed for these three types of sites for the afternoon hours from 1300 to $1700 \mathrm{LT}$; in the case of the city of Bern the time interval was limited to $1600 \mathrm{LT}$.

\subsection{Balloon $\mathrm{H}_{2} \mathrm{O}_{2}$ Measurements}

Figure 3 shows the tracks of the three cruises performed on July 23, 25, and 27, 1990. The balloon started at Attisholz, $25 \mathrm{~km}$ northeast of our research station Schüpberg, and led on July 23 and 25 close to Schüpberg, whereas on July 27 the balloon flew in the opposite direction. Figure 4 compares the $\mathrm{H}_{2} \mathrm{O}_{2}$ measurements of the Schüpberg ground station with those of the balloon flight on July 23. After the start the balloon was transported by the easterly winds close to the ground to the west along the Jura Mountains. Around 1400 LT the inversion layer was crossed and due to the northwesterly winds in the upper layer the direction changed to southeast. There existed a marked difference in $\mathrm{H}_{2} \mathrm{O}_{2}$ concentration between the lower and the upper layer of air. As long as the balloon flew in the lower layer, from 1130 to 1400 and before landing at $1630 \mathrm{LT}$, similar concentrations as in Schüpberg were observed, whereas in the upper layer, concentrations 2 to 3 times as high were measured. At 1500 LT the balloon was exactly over the Schüpberg site. Because of technical problems, $\mathrm{O}_{3}$ could not be measured during the whole cruise and the measurement signal exhibited considerable noise. Nevertheless, it can be seen that the ozone concentration did not show a shift going from the lower to the upper layer. Ozone concentration at Schüpberg agreed with the balloon measurements in the boundary layer (see Figure 2a). The double-layer structure is not a local but a larger-scale feature. Trajectory calculations of the Deutsche Wetterdienst model for 900,850 , and $700 \mathrm{hPa}$ over a 48-hour period exhibited a counterflow situation. While concentrations of ozone in both layers were similar at around $90-100 \mathrm{ppb}$, those of hydrogen peroxide were very different.

The second balloon cruise on July 25 (Figure 5) showed a fairly regular increase of the hydrogen peroxide concentration from 0.5 to $2 \mathrm{ppb}$ during the day, although the height of the flight track varied between 500 and $2000 \mathrm{~m}$ mean sea level (msl). The mixing layer extended up to $1600 \mathrm{~m} \mathrm{msl}$. A sharp rise in the $\mathrm{H}_{2} \mathrm{O}_{2}$ concentration was observed around noon above a small forested hill (Büttenberg), where thermal upwelling carried the balloon up by $200 \mathrm{~m}$. A second sharp rise was observed as the balloon landed in a forest of beech and Norway spruce; the concentration during descending stayed almost constant at 1.9 ppb but jumped to 4 ppb as soon as the basket of the balloon dove into the top of the trees. After we transported the basket out of the forest to a meadow, the concentration dropped to $1.6 \mathrm{ppb}$. This points to a local phenomenon, which could be explained with

Table 3. Average $\mathrm{NO}_{2}$ Concentrations Between 1300 and 1700 LT from July 21 to 28, 1990, at a Rural (Schüpberg), Semirural (Worb), and Urban (Bern, Only 1300-1600 LT) Site

\begin{tabular}{lccl}
\hline Station & Characterization & $\mathrm{NO}_{2}, \mathrm{ppb}$ & $\sigma_{c}$ \\
\hline Schüpberg & rural & 0.84 & 0.9 \\
Worb & semirural & 1.1 & 0.93 \\
Bern & urban & 3.5 & 1.5 \\
\hline
\end{tabular}

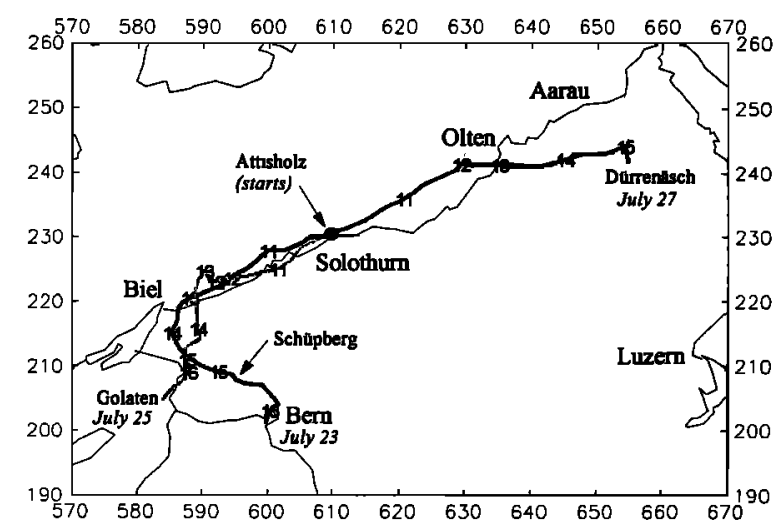

Figure 3. Tracks of the three balloon cruises on July 23, 25, and 27. Axis labels are Swiss kilometer coordinates.

peroxide production from the oxidation of biogenic alkene emissions [Hewitt and Kok, 1991; Lee et al., 1993].

The third flight on July 27 (Figure 6) followed along the Jura Mountains in the northeastern direction until the city of Olten, a region with a lot of traffic and industry, before it turned east into a rural area. This day the inversion layer stayed rather low at around $1200 \mathrm{~m} \mathrm{msl}$. Hydrogen peroxide concentrations were the highest of all three flights, both in the boundary layer and above the inversion layer. Although the Schüpberg ground station also showed the highest value of these days, it still was $40 \%$ less than at the landing site of the balloon. Again, there is a marked difference in concentration between the upper and the lower layer. During this flight the organic peroxides could be measured. It is seen that the concentration expressed as $\mathrm{H}_{2} \mathrm{O}_{2}$ equivalents remains below 0.3 ppbv. Therefore due to the good discrimination between $\mathrm{H}_{2} \mathrm{O}_{2}$ and organic peroxides of the DS system the contribution to the $\mathrm{H}_{2} \mathrm{O}_{2}$ signal is minor, even though the concentration of organic peroxides might be as high as that of $\mathrm{H}_{2} \mathrm{O}_{2}$.

\subsection{Motor Glider Measurements, 1991}

Flights were conducted twice daily (midday and late afternoon) in the Bernese region, along a track extending from the Jura mountain Chasseral and the high-Alpine research station Jungfraujoch. Figure 7 depicts the vertical profile of this flight track together with the $\mathrm{H}_{2} \mathrm{O}_{2}$ concentration. Vertical soundings were not over a fixed location, but ascents form the Bernese region to Jungfraujoch. Figure 8 presents the sequence of such vertical profiles during IOP91 of temperature, potential temperature, water vapor mixing ratio, $\mathrm{O}_{3}, \mathrm{NO}_{2}$, and $\mathrm{H}_{2} \mathrm{O}_{2}$. The temperature and water mixing ratio profiles indicate a multilayered lower troposphere. It is interesting to note that there is no correlation between ozone and hydrogen peroxide concentrations above the inversion layer. The second flight of July 10 shows, for instance, a strongly enhanced layer of $\mathrm{H}_{2} \mathrm{O}_{2}$ between $1500 \mathrm{~m}$ $\mathrm{msl}$ and $2500 \mathrm{~m}$ msl which is not followed by a change in ozone concentration. The same feature can be observed on July 12 around $3500 \mathrm{~m} \mathrm{msl}$. A close flyby at the high-Alpine research station Jungfraujoch, which was equipped with a $\mathrm{H}_{2} \mathrm{O}_{2}$ monitor, showed in that case comparable concentrations for the top layer, confirming the reliability of the motor glider measurements [Lehmann et al., 1992]. Figure 9 shows the correlation of $\mathrm{H}_{2} \mathrm{O}_{2}$ with dew point for all data above the 


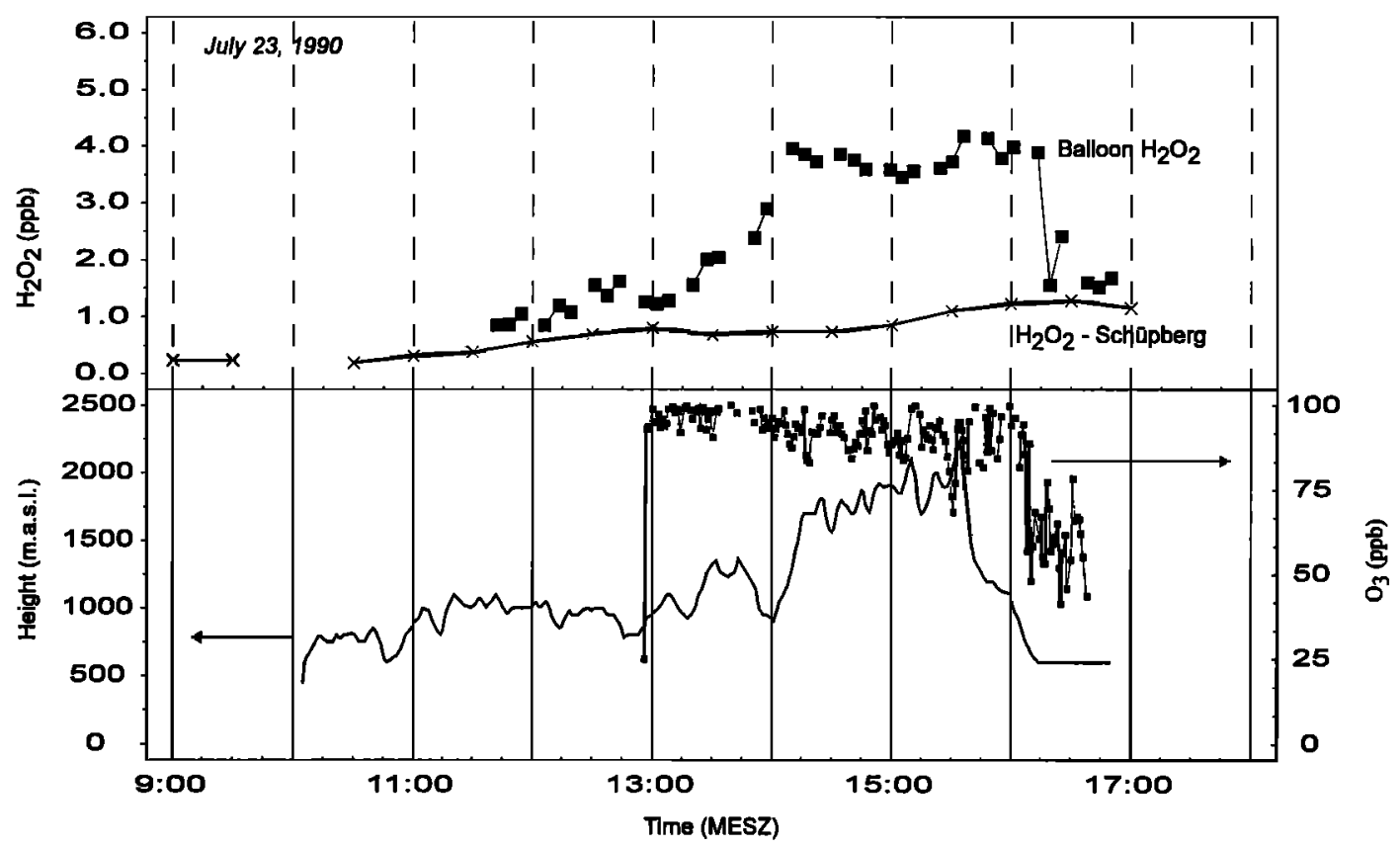

Figure 4. Comparison of balloon $\mathrm{H}_{2} \mathrm{O}_{2}$ data with measurements at Schüpberg on July 23. MESZ is local time.

mixing layer. For comparison, calculated steady state hydrogen peroxide concentrations for the free troposphere for 20 and $200 \mathrm{ppt} \mathrm{NO}_{x}$ are depicted as given by Daum et al. [1990]. The calculated concentrations do not take into account wet and dry deposition processes and thus represent upper limits. It is seen that several data sets are falling into that range, e.g.: (1) the high $\mathrm{H}_{2} \mathrm{O}_{2}$ concentration layer on July 10 (flight 2); July 11 (flight 2); July 12 (flight 1), the top layer with a low dew point but also the range between 1200 and $3500 \mathrm{~m}$ msl with a much higher dew point; and July 12 (flight 2).
The values below this range may have two reasons.

1. The system has not yet built up to a steady state. For some measurements near water vapor saturation conditions existed and therefore variable amounts of $\mathrm{H}_{2} \mathrm{O}_{2}$ may have been previously removed by aqueous phase reactions; for example, July 9 was fairly cloudy and a front moved over the Swiss Plateau.

2. The $\mathrm{NO}_{x}$ level is higher than $200 \mathrm{ppt}$, thus suppressing peroxide production. Because the $\mathrm{NO}_{2}$ measurements with the motor glider exhibited a large uncertainty below $1.5 \mathrm{ppb}$, this could not be examined.

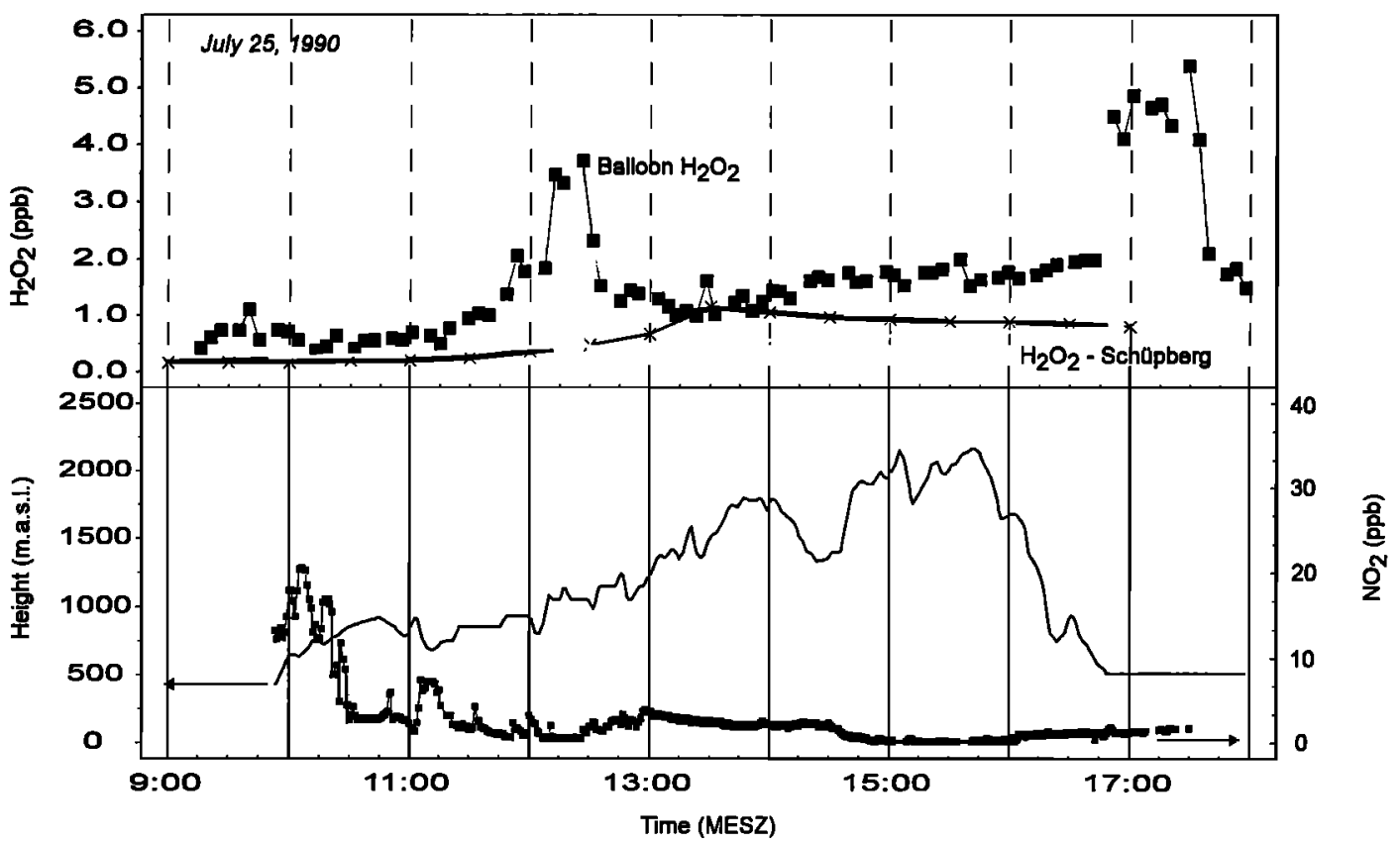

Figure 5. Balloon results from July 25 . 


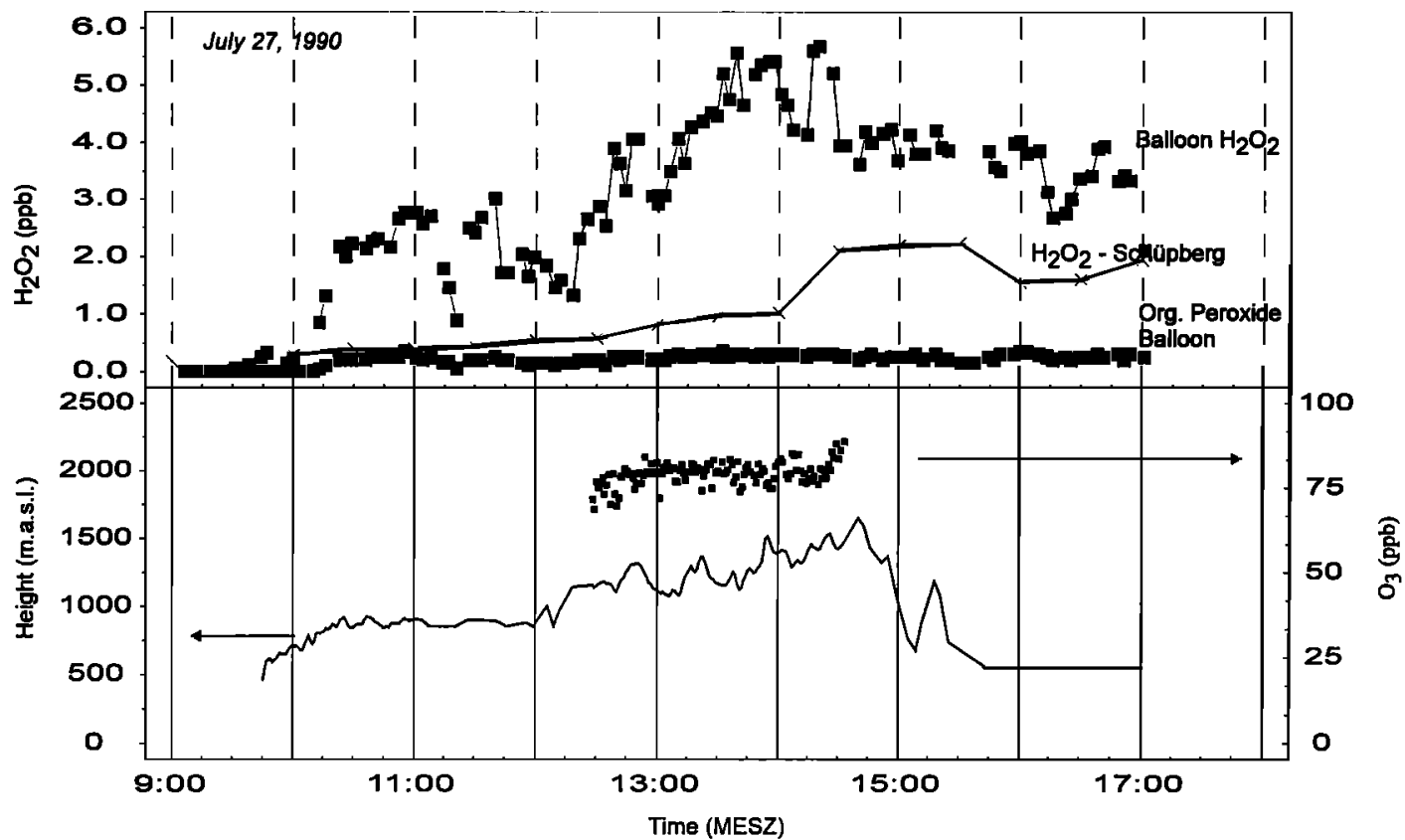

Figure 6. Balloon results from July 27.

Concentrations increased between the two daily flights, most pronounced in the mixing layer, and also increased over the 4-day period from July 9 to 12 . A statistical summary of the hydrogen peroxide measurements divided into values within and above the mixed layer is given in Table 4. In Table 5 we give an estimate of the $\mathrm{H}_{2} \mathrm{O}_{2}$ increase in the mixed layer due to photochemical production between the two daily flights. On July 10 a strong inversion layer around $1200 \mathrm{~m}$ msl was present between the two flights and prevented, to a high degree, air exchange between the planetary boundary layer (PBL) and aloft. The observed increase of $1.1 \mathrm{ppb}$ of the median in the PBL is therefore attributed to photochemical production. On July 11 and 12 the mixing layer grew from $1200 \mathrm{~m} \mathrm{msl}$ to over $2200 \mathrm{~m} \mathrm{msl}$ between flights. Entrainment of air will therefore increase the $\mathrm{H}_{2} \mathrm{O}_{2}$ concentration in the mixed layer. We assume that the median $\mathrm{H}_{2} \mathrm{O}_{2}$ value of the first flight above the mixed

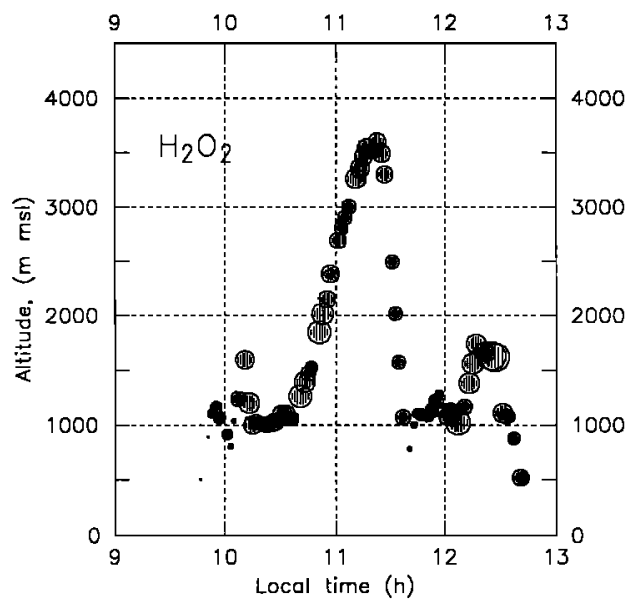

Figure 7. Vertical profile of the first flight of July 11. Size of symbol is proportional to $\mathrm{H}_{2} \mathrm{O}_{2}$ concentration. layer corresponds to the reservoir concentration which is mixed into the PBL during the rise of the mixing height. The photochemical contribution to the increase of hydrogen peroxide in the mixed layer is estimated as the difference between the concentration in the $500-$ to $2200-\mathrm{m}$ column between the first and the second flight.

The measurements at the Schüpberg site yielded peak $\mathrm{H}_{2} \mathrm{O}_{2}$ concentrations of 4-6 ppb on July 10-12, exceeding the flight data. We could not find an instrumental artifact to explain this difference. Water soluble organic peroxides produced from biogenic VOC emissions might be the cause of this observation. The Schüpberg station is situated in an agricultural area and no strong anthropogenic VOC sources are nearby.

The $\mathrm{NO}_{2}$ profile from the July 12 flight exhibits characteristic features of many of the airborne measurements. The late morning flight shows, below the inversion layer, concentrations up to about $10 \mathrm{ppb}$, whereas above it, they drop below 2 ppb. During the afternoon the concentration below the inversion layer, which by then had risen to $2200 \mathrm{~m} \mathrm{msl}$, had also decreased mostly below 1 to $2 \mathrm{ppb}$. As mentioned earlier, an overestimation of up to $1.5 \mathrm{ppb}$ is possible.

\section{Model Calculations and Comparison With Experimental Data}

\subsection{Model Description}

For further interpretation of the data we used 1-dimensional (vertical) boundary layer simulations with the Harvard photochemical model and the Harwell photochemical trajectory model (HPT-M). The Harvard model has been used extensively for simulation of tropospheric chemistry observations [e.g., Fan et al., 1994]. The version used here is based on recent compilations of kinetic and photochemical data [Atkinson, 1990; DeMore et al., 1992; Atkinson et al., 1993]. The UV radiation field is computed with a six-stream code for the Rayleigh scattering atmosphere at $47^{\circ} \mathrm{N}$ in July 

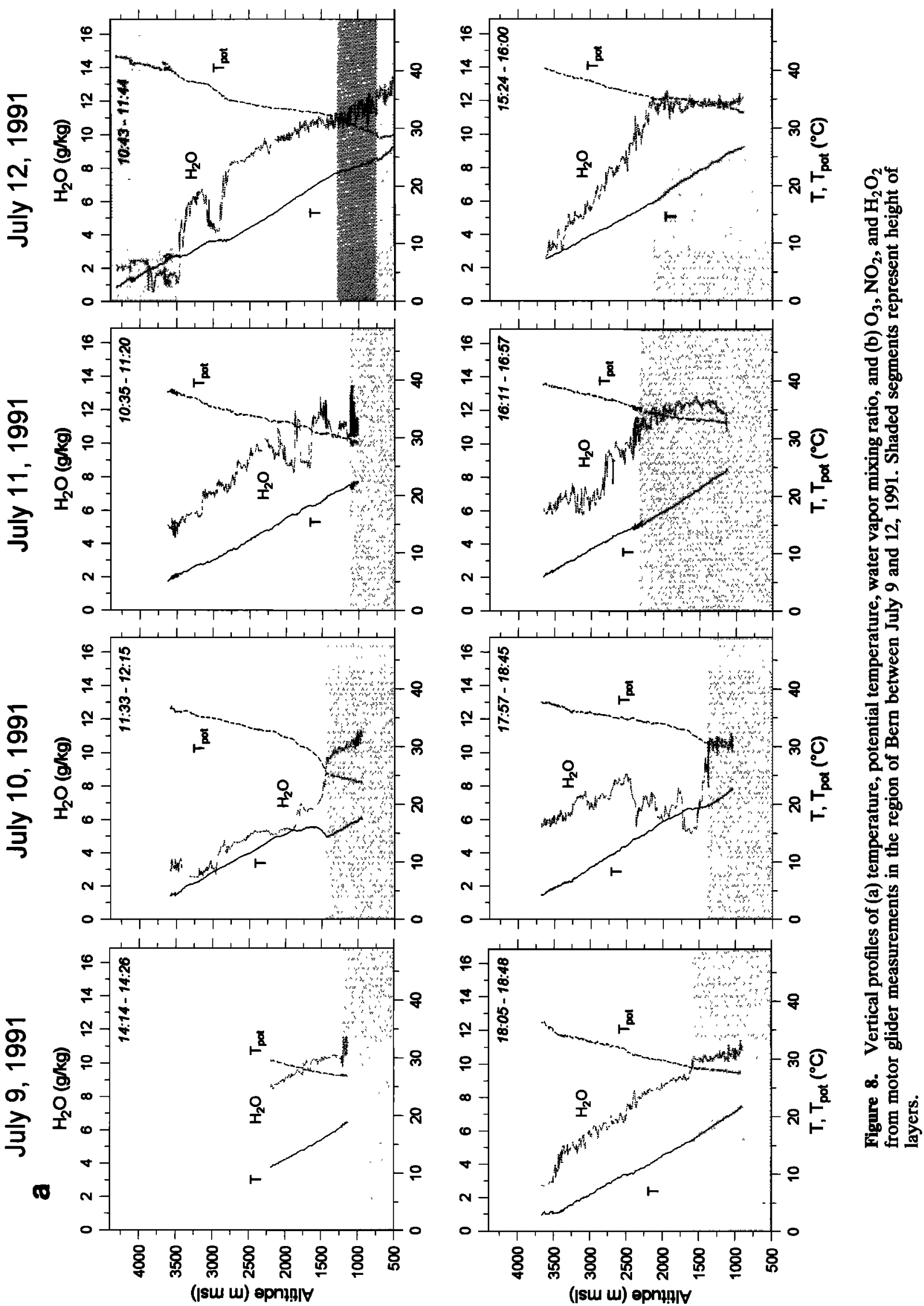

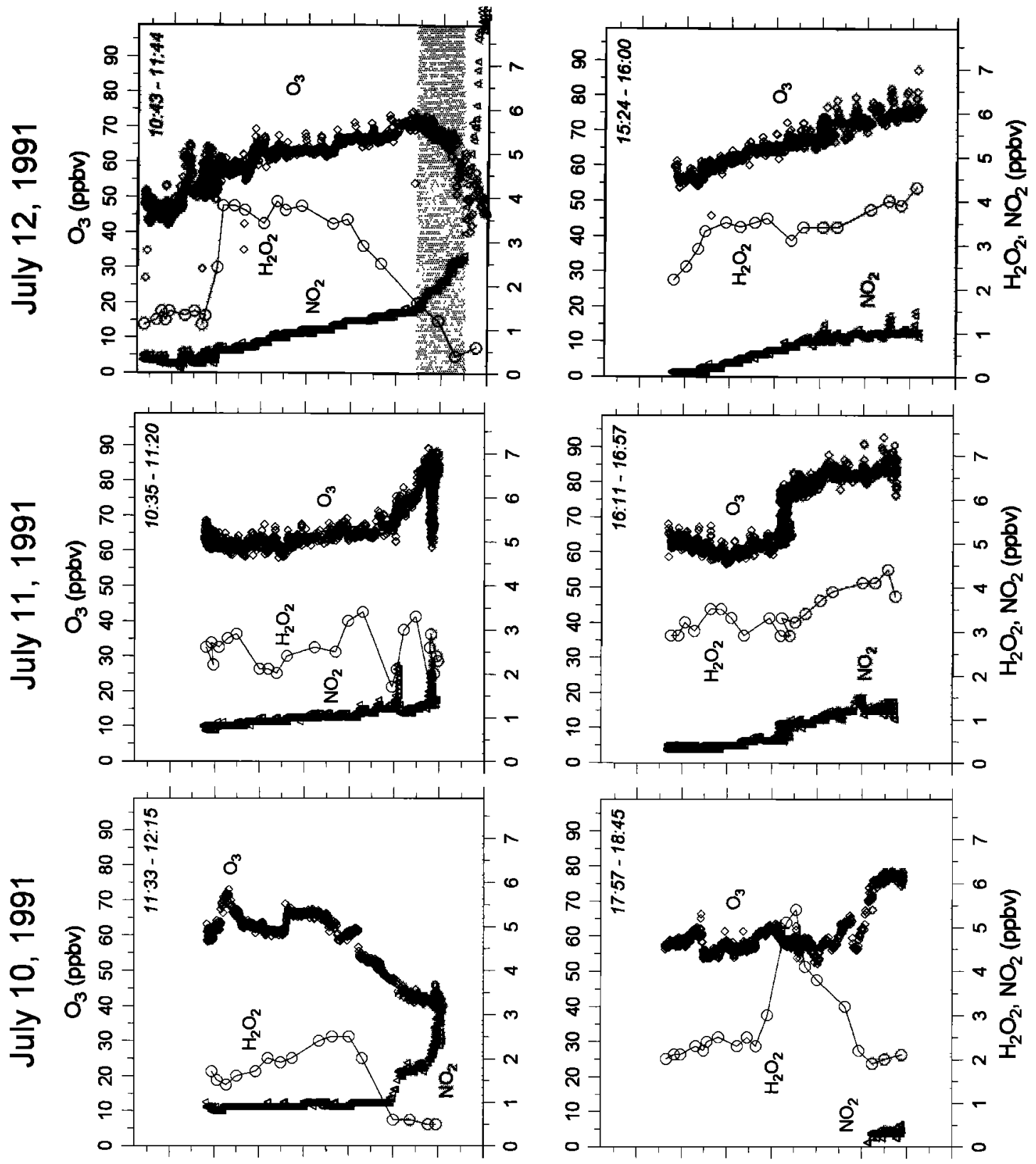

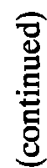
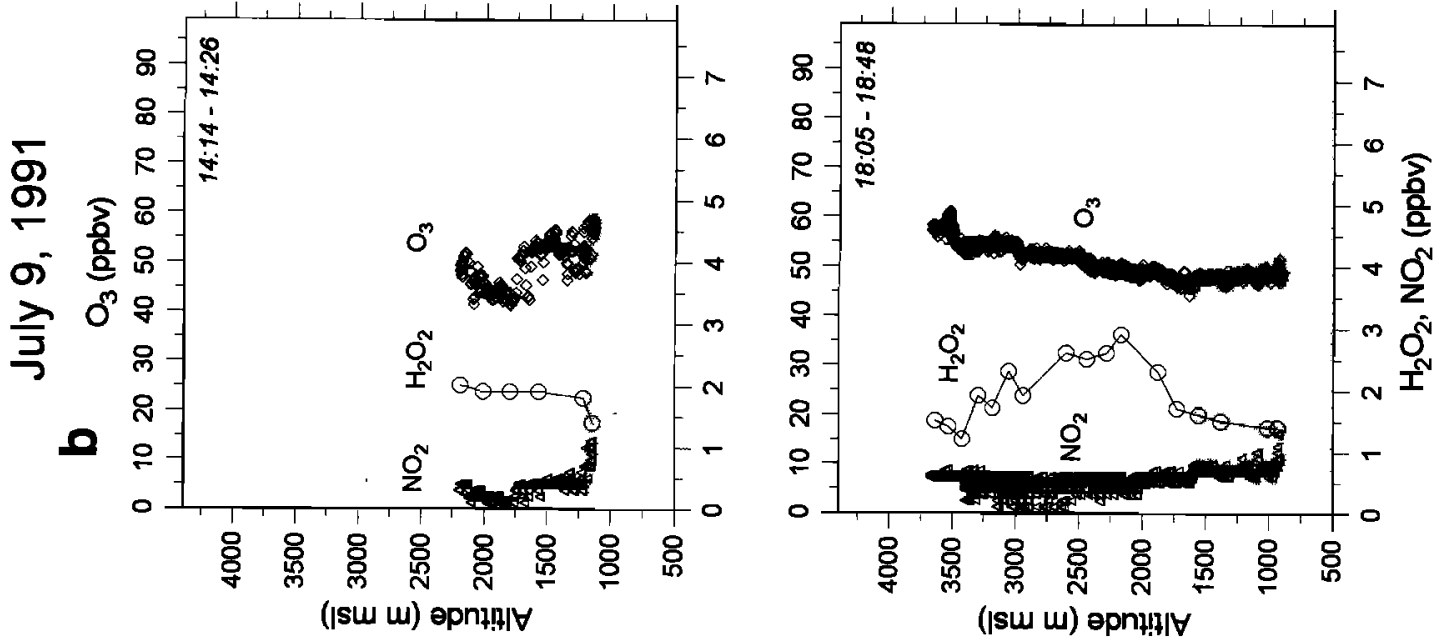


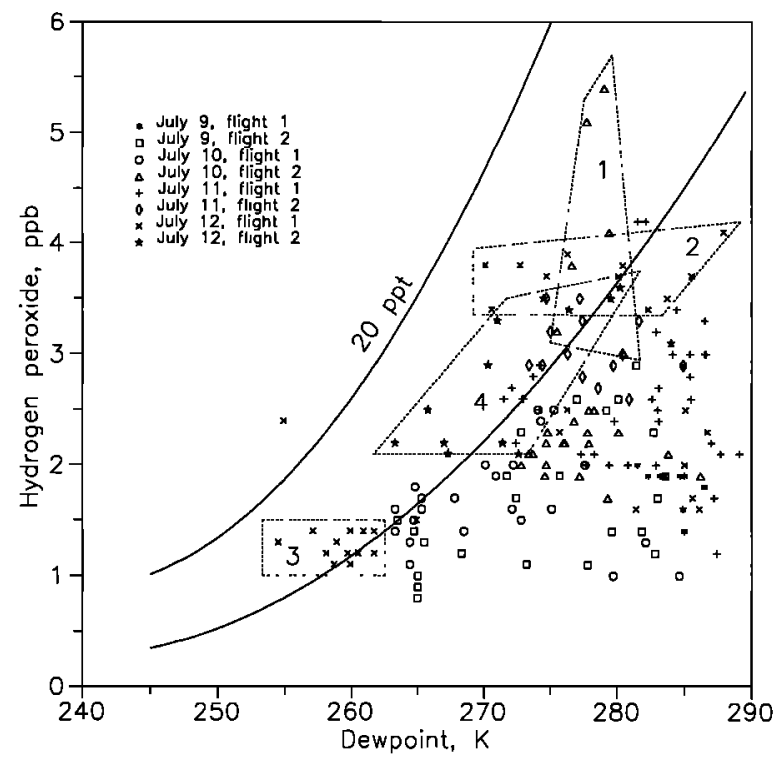

Figure 9. $\mathrm{H}_{2} \mathrm{O}_{2}$ as a function of dew point for all motor glider flights. Data included are above mixing layer given in Table 4. Solid curves are computed $\mathrm{H}_{2} \mathrm{O}_{2}$ concentrations for the free troposphere by Daum et al. [1990] assuming $\mathrm{NO}_{x}$ concentrations of 20 and $200 \mathrm{ppt}$. Areas indicated are (1) flight 2, July 10, layer with high $\mathrm{H}_{2} \mathrm{O}_{2}$ concentration; (2) flight 1, July $12,1200-3500 \mathrm{~m}$ msl; (3) flight 1 , July 12 , above $3500 \mathrm{~m} \mathrm{msl}$; (4) flight 2, July 12.

(solar declination is $22^{\circ}$ ), assuming clear-sky conditions and an $\mathrm{O}_{3}$ column of 330 Dobson units (DU) [Hilsenrath et al., 1979]. The planetary boundary layer is represented by six layers of different spacing, and transport between layers is simulated with eddy diffusion coefficients (Figure 10). The maximum diurnal depth of the mixed layer was taken as $\mathbf{1 3 0 0}$ $\mathrm{m}$, based on data from IOP90 [Künzle and Neu, 1994]. Temperature and water mixing ratios in the different layers were adapted to the observations. A number of gases are removed to the surface with specified dry deposition velocities (Table 6).

The Harwell photochemical trajectory model HPT-M [Derwent and Jenkin, 1990] is a two-layer trajectory model for the boundary layer. Chemistry is restricted to the lower layer (mixed layer); the upper layer is treated as an inert reservoir entraining in the lower layer in the daytime. The depth of the lower layer varies diurnally from $300 \mathrm{~m}$ at night to $1300 \mathrm{~m}$ in the afternoon. The chemical mechanism de-
Table 5. Estimation of Observed $\mathrm{H}_{2} \mathrm{O}_{2}$ Increase in the Mixed Layer due to Photochemical Production and Calculated Values

\begin{tabular}{lccc}
\hline $\begin{array}{c}\text { Flight } \\
\text { Observed* }\end{array}$ & $\begin{array}{c}\text { July 10 } \\
1.1\end{array}$ & $\begin{array}{c}\text { July 11 } \\
1.2\end{array}$ & $\begin{array}{c}\text { July 12 } \\
2.0\end{array}$ \\
\hline Model calculation $\dagger$ & $\begin{array}{l}0.6 \\
\text { day 3 }\end{array}$ & $\begin{array}{l}0.6 \\
\text { day } 4\end{array}$ & $\begin{array}{l}0.5 \\
\text { day } 5\end{array}$ \\
\hline
\end{tabular}

*Average height of ground level is $600 \mathrm{~m} \mathrm{msl}$.

$\dagger$ ifferences are taken from 1000 and 1600 , because local time is solar time plus 2 hours.

scribed by Derwent and Jenkin [1990] was slightly modified using the new compilation of rate constants for the inorganic reactions [Atkinson et al., 1993]. The photolysis rates of $\mathrm{NO}_{2}, \mathrm{H}_{2} \mathrm{CO}$, and $\mathrm{O}_{3}$ to $\mathrm{O}\left({ }^{1} D\right)$ were adopted from the Harvard model.

Emissions of $\mathrm{NO}_{x}$, fractionated hydrocarbons, and $\mathrm{CO}$ were specified with $50 \mathrm{~km} \times 50 \mathrm{~km}$ resolution from the inventory developed by the Organization for Economic Cooperation and Development (OECD) [Lübkert et al., 1989]. This inventory, compiled for the year 1980, has been updated for Switzerland by the Federal Office for the Environment, Forests and Landscape (BUWAL) for the summer 1990 [Rosselet and Kerr, 1993]. Natural organic emissions were not included in the emission inventory. Anthropogenic VOC emissions (ng $\mathrm{C} / \mathrm{m}^{2}$ s) over the Swiss Plateau in summer are about 5 times higher than biogenic VOC emissions, which are mainly terpenes [Andreani-Aksoyoglu and Keller, 1994].

\subsection{Trajectory Studies}

The July 24-26, 1990, period was characterized by anticyclonic conditions, clear skies, and slow easterly winds, lending some justification for a 1-dimensional modeling approach. Episodes with high ozone levels are often related to such meteorological situations. We considered a boundary layer column arriving at Schüpberg (Bern) on the evening of July 26 and estimated the transport history of that air column over the past days using trajectory analyses from Neu [Künzle and Neu, 1994] over Switzerland and from the Deutsche Wetterdienst over Germany. It appears from these analyses that the boundary layer column over Schüpberg on July 26 had originated over southeast Germany three days before. We computed the photochemical evolution of the boundary layer column along this 3-day trajectory assuming

Table 4. Statistical Summary of $\mathrm{H}_{2} \mathrm{O}_{2}$ Concentration (parts per billion by volume) Above and in the Mixing Layer (ML) of All Motor Glider Measurements Between July 9 and 12, 1991

\begin{tabular}{|c|c|c|c|c|c|c|c|}
\hline \multirow[b]{2}{*}{ Flight, LT } & \multirow{2}{*}{$\begin{array}{l}\text { Mixing Layer } \\
\text { Height, m msl }\end{array}$} & \multicolumn{3}{|c|}{ Above ML } & \multicolumn{3}{|c|}{ Within $\mathbf{M L}$} \\
\hline & & Median & $50 \%$ Range* & Range & Median & 50\% Range* & Range \\
\hline July $9,1359-1536$ & 1200 & 1.9 & $1.9-1.9$ & $1.4-2.0$ & 1.6 & $1.4-1.8$ & $1.1-2.2$ \\
\hline July $9,1710-1935$ & 1600 & 1.5 & $1.2-1.9$ & $0.8-2.9$ & 1.5 & $1.2-1.8$ & $0.8-2.4$ \\
\hline July $10,1039-1344$ & 1500 & 1.6 & $1.3-1.9$ & $1.0-2.5$ & 0.6 & $0.4-0.8$ & $0.3-2.7$ \\
\hline July $10,1738-1943$ & 1500 & 2.2 & $2.0-2.4$ & $1.7-5.4$ & 1.7 & $1.5-1.9$ & $1.3-2.4$ \\
\hline July $11,0946-1242$ & 1200 & 2.6 & $2.2-3.0$ & $1.2-4.2$ & 2.0 & $1.6-2.4$ & $0.2-3.6$ \\
\hline July $11,1528-1841$ & 2300 & 3.0 & $2.8-3.2$ & $2.6-3.5$ & 3.6 & $3.2-4.0$ & $2.2-4.7$ \\
\hline July $12,1040-1228$ & 1200 & 2.2 & $1.2-2.9$ & $1.1-4.1$ & 1.3 & $1.2-1.7$ & $0.4-2.7$ \\
\hline July $12,1502-1629$ & 2200 & 2.9 & $2.2-3.6$ & $2.1-3.6$ & 3.9 & $3.7-4.2$ & $2.0-4.3$ \\
\hline
\end{tabular}

${ }^{*}$ Range of the middle half of the data. 


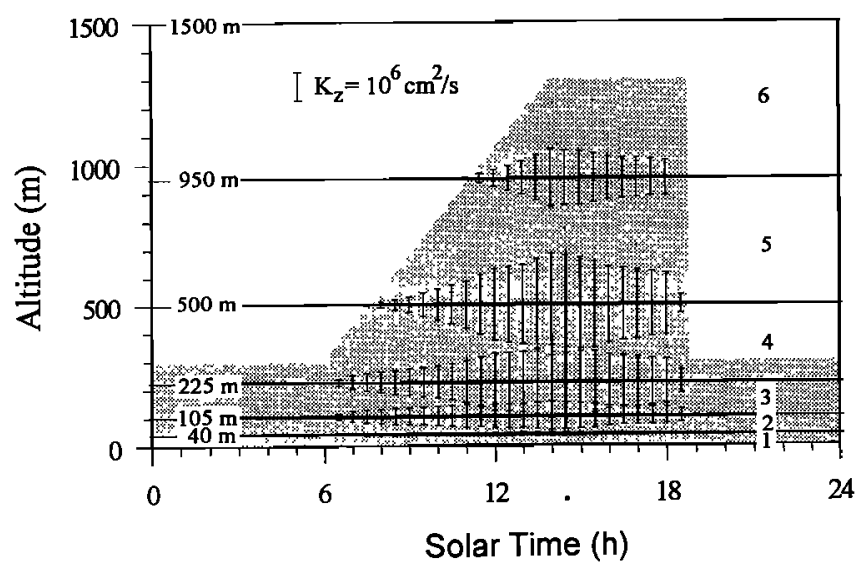

Figure 10. The six model levels, the diurnally varying exchange coefficients, and mixing height used in the Harvard photochemical model.

clear skies and specifying temperature, humidity, and boundary layer height from meteorological data along the trajectory. Figure 11 shows the time series of surface ozone computed with the HPT-M for July 24-26, together with observations at rural sites along the trajectory of the air column. The model is successful at reproducing the observed daily maxima. Concentrations of $\mathrm{NO}_{2}$ at Schüpberg in the model were around $1 \mathrm{ppb}$, in agreement with measurements (Figure 2, Table 3).

We defined the transition between the $\mathrm{NO}_{x}$ - and the VOC-limited regimes for $\mathrm{O}_{3}$ production by conducting simulations with emissions modified by fractional increments from the base case (taken as 100\%). We chose for this purpose an idealized trajectory starting over the Lake of Constance at $1800 \mathrm{LT}$ and reaching the area of Bern at late afternoon of the following day. Initial concentrations are given in Table 7. The resulting isopleths of ozone and $\mathrm{H}_{2} \mathrm{O}_{2}$ concentrations after one day are shown in Figure 12. We see that the $\mathrm{H}_{2} \mathrm{O}_{2}$ concentration is a sensitive indicator of photochemical regime, decreasing rapidly as ozone production evolves from low- $\mathrm{NO}_{x}$ to high- $\mathrm{NO}_{x}$ regimes. The base case in the HPT-M is on the ridge of the transition region between $\mathrm{NO}_{x}$ - and VOC-limited $\mathrm{O}_{3}$ production; in the

Table 6. Dry Deposition Velocities (centimeters per second) Used in the Harvard and HPT Models

\begin{tabular}{lccc}
\hline & \multicolumn{2}{c}{ Multiday Calculation } & \\
\cline { 2 - 3 } \multicolumn{1}{c}{ Species } & $\begin{array}{c}\text { Day, } \\
\text { 0600-1800 ST }\end{array}$ & $\begin{array}{c}\text { Night, } \\
\text { 1800-0600 ST }\end{array}$ & $\begin{array}{c}\text { Trajectory, } \\
\text { Day/Night }\end{array}$ \\
\hline $\mathrm{O}_{3} \mathrm{H}_{2} \mathrm{O}_{2}$ & 0.6 & 0.12 & 0.5 \\
$\mathrm{CH}_{3} \mathrm{O}_{2} \mathrm{H}$ & 2.0 & 0.4 & 0.5 \\
$\mathrm{Other} \mathrm{peroxides}_{\mathrm{NO}_{2}}$ & 0.5 & 0.1 & 0.2 \\
Peroxyacetylnitrates & 0.2 & 0.04 & 0.2 \\
$\quad$ (PAN) & 0.4 & 0.08 & 0.15 \\
Aldehydes & 0.2 & 0.04 & 0.2 \\
$\mathrm{HNO}_{3}$ & 0.2 & 0.04 & 0.2 \\
\hline
\end{tabular}

*ST, solar time.

$\uparrow$ Deposition velocities are calculated by means of the resistance analogy with $R_{c}$ (surface resistance) $=0 ; 24$-hour average deposition velocity is $1.2 \mathrm{~cm} / \mathrm{s}$, during daytime $5 \mathrm{~cm} / \mathrm{s}$.

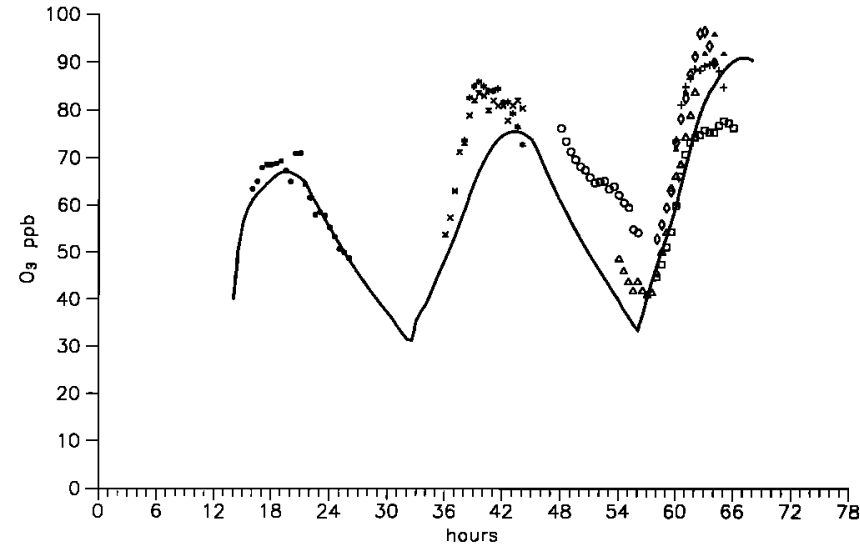

Figure 11. Calculation of the ozone concentration along a trajectory from the Thüringerwald, Munich, to Lake of Constance, Zürich, into the region of Bern on July 24-26, 1990. Symbols correspond to ground-based measurements along the trajectory: solid circles, Brotjacklriegel; crosses, Stuelegg; asterisks, Friedrichshafen; open circles, Haselberg; open triangles, Hohenrain; diamonds, Bleichenberg; squares, Langenthal; pluses, Schupberg; solid triangles, Payerne.

Harvard model the base case is more squarely in the low- $\mathrm{NO}_{x}$ regime. This difference between the two models appears to reflect principally the more rapid dilution of $\mathrm{NO}_{x}$ emissions in the Harvard model during daytime and the reduced $\mathrm{O}_{3}$ deposition due to restricted dilution during nighttime. $\mathrm{H}_{2} \mathrm{O}_{2}$ concentrations in the models are in the range of the observed values, although this agreement reflects in part the initial conditions; the simulated increase in day-to-day peak concentration in the mixed layer is in agreement with observations. For this calculation a lowdeposition velocity, $0.5 \mathrm{~cm} / \mathrm{s}$, as for ozone was used. There have been few measurements of $\mathrm{H}_{2} \mathrm{O}_{2}$ dry deposition velocities; however, the limited studies suggest that it is higher in a manner similar to that of $\mathrm{HNO}_{3}$. Therefore the computed increases of $\mathrm{H}_{2} \mathrm{O}_{2}$ reflect upper limits. Higher-deposition rates of $2 \mathrm{~cm} / \mathrm{s}$ decrease $\mathrm{H}_{2} \mathrm{O}_{2}$ production by $\sim 0.3 \mathrm{ppb}$ for the Harvard model and $0.5 \mathrm{ppb}$ for the HPT-M, respectively. In this case, the HPT-M would predict no net peroxide production over 24 hours. However, at Schüpberg, increas-

Table 7. Initial Concentrations in parts per billion (ppbC VOC) for the Multiday Calculations of the Harvard Model and for the Trajectory Calculations of Both Models

\begin{tabular}{lcc}
\hline Species & $\begin{array}{c}\text { Multiday } \\
\text { Calculations }\end{array}$ & Trajectory \\
\hline $\mathrm{O}_{3}$ & 40 & 78 \\
$\mathrm{NO}_{2}$ & 0.7 & 0.7 \\
$\mathrm{NO}$ & 0.08 & 0.08 \\
$\mathrm{CO}$ & 200 & 250 \\
$\mathrm{H}_{2} \mathrm{O}_{2}$ & 1.0 & 1.6 \\
$\mathrm{CH}_{3} \mathrm{O}_{2} \mathrm{H}$ & 0.4 & 0.4 \\
$\mathrm{PAN}^{\mathrm{HNO}}$ & 0.6 & 0.6 \\
$\mathrm{CH}_{4}$ & 0.07 & 5.1 \\
VOC & 1700 & 2000 \\
& 11.2 & 11.2 \\
\hline
\end{tabular}

The values for the latter are the concentrations after the initialization run over southern Germany. 

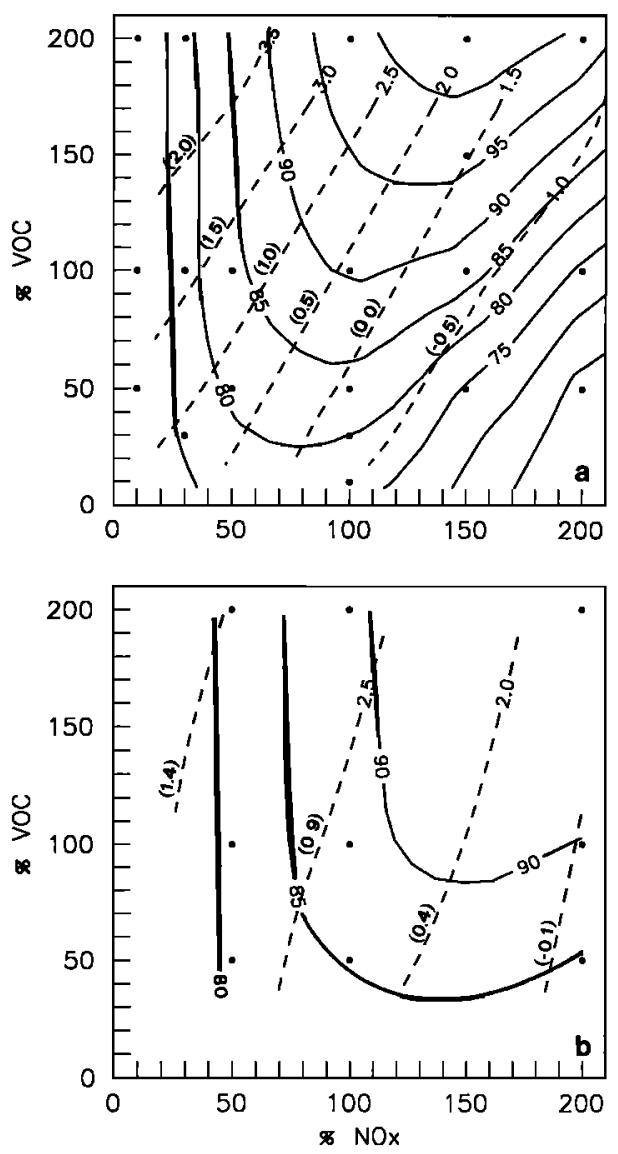

Figure 12. Ozone (solid curves) and $\mathrm{H}_{2} \mathrm{O}_{2}$ (dashed) isopleths as a function of $\mathrm{NO}_{x}$ /volatile organic compound (VOC) emissions relative to the base year 1990 calculated from (a) the HPT-M and (b) the Harvard photochemical model. Concentrations are in parts per billion by volume. In parentheses are the differences between initial and final concentrations ( 23 hours). For the Harvard model, concentrations are given for the lowest layer.

ing hydrogen peroxide concentrations were observed during two periods of easterly winds.

Figure 13 shows the dependence of the calculated $\mathrm{NO}_{2}$ concentration at the time of the ozone maximum from the HPT-M (cross section of Figure 12 at the $100 \%$ VOC level). In the low- $\mathrm{NO}_{x}$ regime the $\mathrm{NO}_{2}$ concentration dependence from the emissions is weaker than in the high $\mathrm{NO}_{x}$ regime. The turning point happens around $150 \% \mathrm{NO}_{x} / 100 \%$ VOC. Our $\mathrm{NO}_{2}$ measurements with the DOAS instrument are in agreement with the low-NO $\mathrm{NO}_{x}$ branch of this curve (see Table 3).

Flight measurements in 1991 yield information across the Bernese area and the temporal development between morning and afternoon. To understand the photochemical activity, we performed model simulations with the Harvard model under the approximation of a stationary column over that area. Emissions of the grid cell in the central part of Switzerland (indicated in Figure 1); which is representative of average emissions of the Swiss Plateau, were chosen. The simulation was conducted for 8 days with diurnally varying emissions [Sigg and Neftel, 1993] and mixing height (Figure 10). The initial concentrations chosen are given in Table 7. $\mathrm{H}_{2} \mathrm{O}_{2}$ and $\mathrm{O}_{3}$ concentrations show steadily increasing con- centrations and strongly varying values in the lowest layers, as can be seen in Figure 14. The increase of the ozone concentration slows down after a few days. Even after 8 days, the concentration does not surpass $100 \mathrm{ppb}$, in agreement with observations [Künzle and Neu, 1994].

The physical and chemical interplay concerning the production of $\mathrm{H}_{2} \mathrm{O}_{2}$ can be clearly seen in the model. In the afternoon a thoroughly mixed boundary layer leads to a small vertical concentration gradient. During the night, $\mathrm{H}_{2} \mathrm{O}_{2}$ decreases due to deposition, particularly in the lowest layer. With the onset of the vertical mixing in the morning, $\mathrm{H}_{2} \mathrm{O}_{2}$ is mixed down, which produces a sharp increase at ground level. Net production of $\mathrm{H}_{2} \mathrm{O}_{2}$ takes place in the morning, when $\mathrm{NO}_{x}$ concentrations are relatively low. This $\mathrm{H}_{2} \mathrm{O}_{2}$ mixes down over the course of the day, producing the daily net increase of $\mathrm{H}_{2} \mathrm{O}_{2}$ of about $0.3-0.5 \mathrm{ppb}$. The rise of $\mathrm{H}_{2} \mathrm{O}_{2}$ from morning to afternoon in the model is about half of observed values (Table 5). It is also interesting to note that on July 11 and 12 , hydrogen peroxide concentrations decrease with height opposite to the model behavior. This points to a pronounced peroxide production near the surface. The photochemical regime for ozone production appears therefore to be more $\mathrm{NO}_{x}$ limited than indicated by the models based on the standard emission inventory.

\section{Summary and Conclusions}

The important results of the observations were the following: (1) $\mathrm{H}_{2} \mathrm{O}_{2}$ concentrations ranged between 1 and $6 \mathrm{ppb}$. Elevated local concentrations could be due to biogenic VOC emissions. During the buildup of a regional $\mathrm{O}_{3}$ smog episode, increasing hydrogen peroxide concentrations were observed. (2) Peak ozone concentrations in this highly industrialized and densely populated area level off at around 80-100 ppb. (3) Ground-based mean $\mathrm{NO}_{2}$ concentrations in the afternoon in rural and semirural areas are below $1.5 \mathrm{ppb}$.

Two photochemical trajectory models were used to calculate ozone and hydrogen peroxide production over the Swiss Plateau. Calculated isopleths from the Harvard photochemical model show a low- $\mathrm{NO}_{x}$ type ozone production, whereas for the HPT-M it is in the transition range. However,

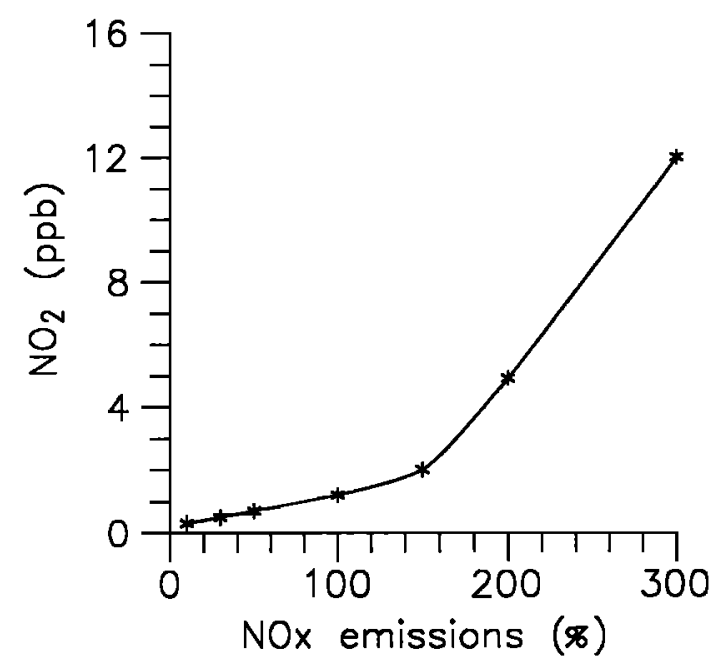

Figure 13. Calculated $\mathrm{NO}_{2}$ concentration from the HPT-M expressed as a function of $\mathrm{NO}_{x}$ emission at $100 \%$ VOC emission. 

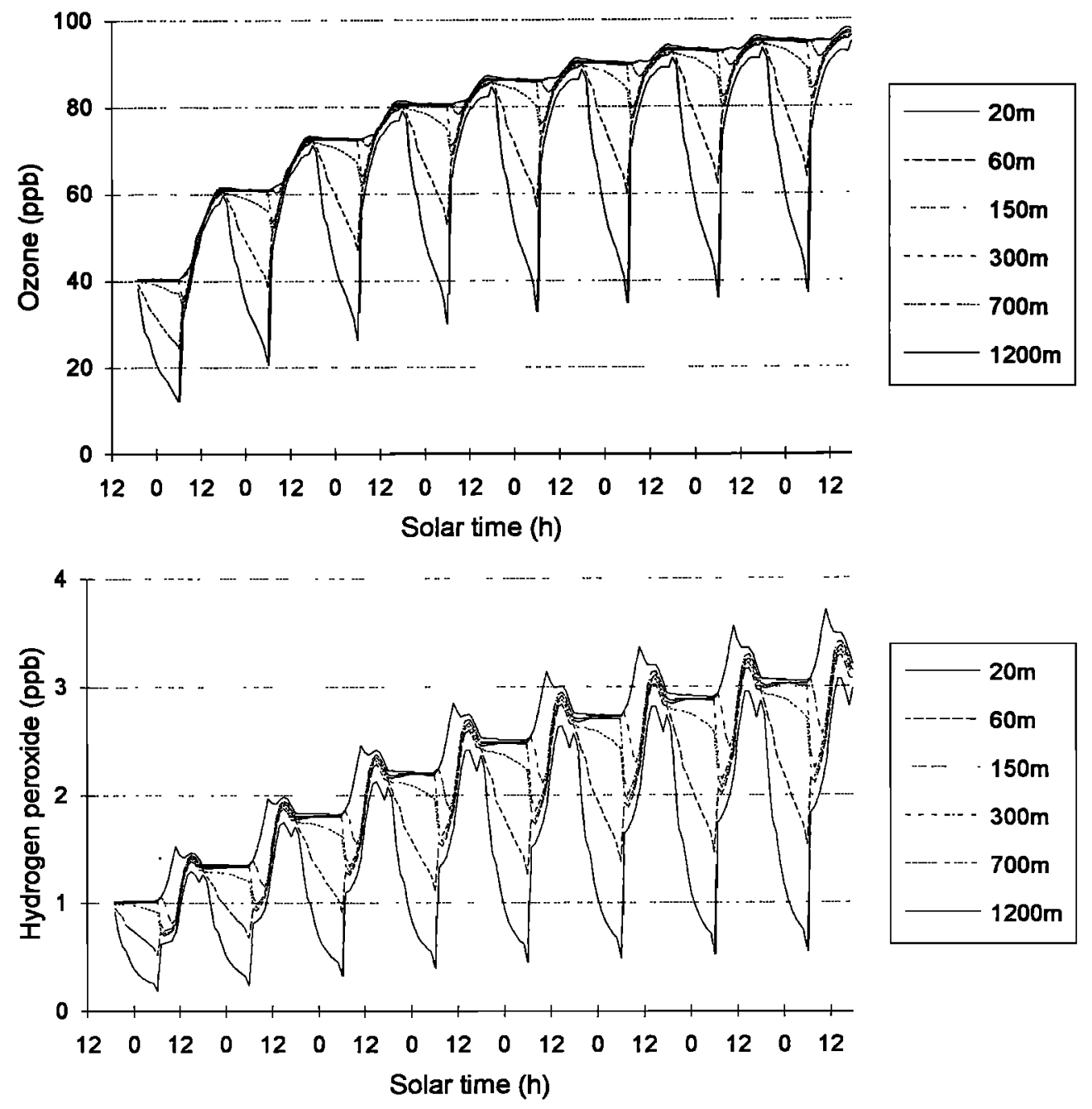

Figure 14. Base-case 8-day run with the Harvard model. Results for $\mathrm{O}_{3}$ and $\mathrm{H}_{2} \mathrm{O}_{2}$.

hydrogen peroxide production in the mixing layer is underestimated. This points to an underestimation of the VOC/ $\mathrm{NO}_{x}$ emission ratio (e.g., due to the neglect of biogenic hydrocarbons, underestimation of anthropogenic VOC, or overestimation of $\mathrm{NO}_{x}$ emissions) and indicates a $\mathrm{NO}_{x}$ limited regime for ozone production.

Acknowledgments. This work was sponsored by the Federal Office for the Environment, Forests and Landscape (BUWAL) and by the Swiss Office for Science and Education through the COST action 611 "physico-chemical behaviour of atmospheric pollutants." We wish to thank B. Neininger and W. Fuchs from MetAir for the flight measurements and H.-J. Fröhlin for the safe guidance of the hydrogen balloon. The work at Harvard was supported by the National Science Foundation (ATM-93-04217). We thank C. M. Spivakovsky for guidance with the Harvard model.

\section{References}

Andreani-Aksoyoglu, S., and J. Keller, Estimates of monoterpene and isoprene emissions from the forests in Switzerland, J. Atmos. Chem., 20, 1-17, 1995.

Atkinson, R., Gas phase tropospheric chemistry of organic compounds: A review, Atmos. Environ., 24(A), 1-41, 1990.

Atkinson, R., D. L. Baulch, R. A. Cox, R. F. Hampson Jr., J. A. Kerr, and J. Troe, Evaluated kinetic and photochemical data for atmospheric chemistry: Supplement IV, IUPAC subcommittee on gas kinetic data evaluation for atmospheric chemistry, J. Phys. Chem. Ref. Data, 21, 1125-1568, 1993.

Dasgupta, P. K., S. Dong, H. Hwang, H. C. Yang, and Z. Genfa, Continuous liquid-phase fluorometry coupled to a diffusion scrubber for real-time determination of atmospheric formaldehyde, hydrogen peroxide and sulfur dioxide, Atmos. Environ., 22, 949-963, 1988.

Daum, P. H., L. I. Kleinman, A. J. Hills, A. L. Lazrus, A. C. D. Leslie, K. Busness, and J. Boatman, Measurement and interpretation of concentrations of $\mathrm{H}_{2} \mathrm{O}_{2}$ and related species in the upper Midwest during summer, J. Geophys. Res., 95, 9857-9871, 1990.

DeMore, W. B., S. P. Sander, D. M. Golden, M. J. Molina, R. F. Hampson, C. E. Kolb, M. J. Kurylo, C. J. Howard, and A. R. Ravishankara, Chemical kinetics and photochemical data for use in stratospheric modeling, JPL Publ. 92-20, Jet Propul. Lab., Pasadena, Calif., 1992.

Derwent, R. G., and M. E. Jenkin, Hydrocarbon involvement in photochemical ozone formation in Europe, AERE Rep-R13736, At. Energ. Res. Estab., (HMSO) London, 1990.

Drummond, J. W., C. Castledine, J. Green, R. Denno, G. I. Mackay, and H. I. Schiff, New Technologies for use in acid deposition networks, in Monitoring Methods for Toxics in the Atmosphere, edited by W. L. Zielinski Jr., Spec. Tech. Publ. 1052, pp. 133-149, Am. Soc. for Testing and Mater., Philadelphia, Pa., 1989.

Fan, S.-M., D. J. Jacob, D. L. Mauzerall, J. D. Bradshaw, S. T. Sandholm, D. R. Blake, H. B. Singh, R. W. Talbot, G. L. Gregory, and G. W. Sachse, The origin of tropospheric NOx over 
subarctic eastern Canada, J. Geophys. Res., 99, 16,867-16,877, 1994.

Heikes, B. G., Formaldehyde and hydroperoxides at Mauna Loa Observatory, J. Geophys. Res., 97, 18,001-18,013, 1992.

Hewitt, C. N., and G. L. Kok, Formation and occurrence of organic hydroperoxides in the troposphere: Laboratory and field observations, J. Atmos. Chem., 12, 181-194, 1991.

Hilsenrath, E., D. F. Heath, and B. M. Schlesinger, Seasonal and interannual variations in total ozone revealed by Nimbus 4 backscattered ultraviolet experiment, J. Geophys. Res., 84, 69696979, 1979.

Kelly, T. J., C. W. Spicer, and G. F. Ward, An assessment of the luminol chemiluminescence technique for measurement of the $\mathrm{NO}_{2}$ in ambient air, Atmos. Environ., 24(A), 2397-2404, 1990.

Kleinman, L. I., Photochemical formation of peroxides in the boundary layer, J. Geophys. Res., 91, 10,889-10,904, 1986.

Kleinman, L. I., Seasonal dependence of boundary layer peroxide concentration: The low and high $\mathrm{NO}_{x}$ regimes, J. Geophys. Res., 96, 20,721-20,733, 1991.

Künzle, T., and U. Neu, Experimentelle Studien zur räumlichen Struktur und Dynamik des Sommersmogs über dem Schweizer Mittelland, Ph.D. thesis, Univ. of Bern, 1994.

Lazrus, A. L., G. L. Kok, J. A. Lind, S. N. Gitlin, B. G. Heikes, and R. E. Shetter, Automated fluorometric method for hydrogen peroxide in air, Anal. Chem., 58, 594-597, 1986.

Lee, J. H., D. F. Leahy, I. N. Tang, and L. Newman, Measurement and speciation of gas phase peroxides in the atmosphere, $J$. Geophys. Res., 98, 2911-2915, 1993.

Lehmann, M., A. Sigg, B. E. Lehmann, and A. Neftel, $\mathrm{H}_{2} \mathrm{O}_{2}$ concentration during summer smog situations at the high alpine research station Jungfraujoch, Air Pollut. Res. Rep. 39, pp. 17-22, 1992.

Lind, J. A., and G. L. Kok, Henry's law determinations for aqueous solutions of hydrogen peroxide, methylhydroperoxide and peroxyacetic acid, J. Geophys. Res., 91, 7889-7895, 1986.

Lübkert, B., and S. De Tilly, The OECD-MAP emission inventory for $\mathrm{SO}_{2}, \mathrm{NO}_{x}$ and VOC in western Europe, Atmos. Environ., 23, $3-15,1989$.
Neininger, B., and W. Fuchs, Air pollution measurements with a light aircraft (MetAir's Stemme S10 VC), in Proceedings of the Sixth European Symposium on Physico-chemical Behaviour of Atmospheric Pollutants, Rep. EUR 15609/2EN, Off. for Official Publ. of the Eur. Community, Luxembourg, 1994.

Rosselet, C. M., and J. A. Kerr, Photochemical modelling of photo-oxidant levels over the Swiss Plateau and emission reduction scenarios, PSI Ber. 93-03, Paul Scherrer Inst., Villigen, Switzerland, 1993.

Sigg, A., and A. Neftel, Vorkommen und vertikale Verteilung von Peroxiden in der Schweiz, FAC-Schr. 14 Eidg. Forsch. Agr. Umwelthyg., CH-3097, 1993.

Sigg, A., B. E. Lehmann, M. Lehmann, and A. Neftel, $\mathrm{H}_{2} \mathrm{O}_{2}$ measurements in the boundary layer over Switzerland during summer smog episodes, Air Pollut. Res. Rep. 39, pp. 23-27, 1992a.

Sigg, A., A. Neftel, and P. K. Dasgupta, A miniaturized, battery powered $\mathrm{H}_{2} \mathrm{O}_{2}$ monitor for airborne measurements in a motor glider, in Air Pollut. Res. Rep. 41, pp. 111-117, 1992b.

Staffelbach, T. A., and G. L. Kok, Henry's law constants for aqueous solutions of hydrogen peroxide and hydroxymethyl hydroperoxide, J. Geophys. Res., 98, 12,713-12,717, 1993.

Wanner, H., T. Künzle, U. Neu, B. Ihly, G. Baumbach, and B Steisslinger, On the dynamics of photochemical smog over the Swiss middleland-Results of the first POLLUMET field experiment, Meteorol. Atmos. Phys., 51, 117-138, 1993.

J. Dommen, Luftschadstoffe, PSI, 5232, Villigen, Switzerland. D. J. Jacob, Earth and Planetary Sciences, Division of Applied Science, Harvard University, Cambridge, MA 02138.

A. Neftel (corresponding author) and A. Sigg, Swiss Federal Research Station for Agricultural Chemistry and Environmental Hygiene, Liebefeld-Bem, Switzerland.

(Received December 1, 1993; revised September 9, 1994; accepted November 29, 1994.) 